\title{
CURRENT STATUS OF BAT DIVERSITY AND CONSERVATION IN UNIVERSITI PUTRA MALAYSIA AND ITS FOREST RESERVES
}

\author{
MARINA, M.T. ${ }^{1,4 *}$, CHUBO, J.K. ${ }^{2}$, SENAWI, J. ${ }^{3}$, NUR FARRAZUIN, J. ${ }^{4}$ AND AHMAD BADRUL \\ AMIN, A. R. ${ }^{4}$ \\ ${ }^{1}$ Centre of Foundation Studies for Agricultural Sciences, Universiti Putra Malaysia, 43400, Serdang, Selangor. ${ }^{2}$ Department \\ of Forestry Science, Faculty of Agricultural Science and Forestry, Universiti Putra Malaysia Bintulu Sarawak Campus, \\ 97000, Bintulu, Sarawak. ${ }^{3}$ Department of Biological Sciences and Biotechnology, Faculty of Science and Technology, \\ Universiti Kebangsaan Malaysia, 43600, Bangi, Selangor. ${ }^{4}$ Department of Biology, Faculty of Science, Universiti Putra \\ Malaysia, 43400, Serdang, Selangor.
}

*Corresponding author: marinamohd@upm.edu.my

Submitted final draft: 6 April $2021 \quad$ Accepted: 14 April 2021

http://doi.org/10.46754/jssm.2021.10.018

\begin{abstract}
Universiti Putra Malaysia consists of three main areas, namely Serdang main campus in Selangor (UPMSC), Bintulu campus in Sarawak (UPMKB) and the UPM forest in Ayer Hitam Forest Reserve (AHFR) in Puchong, Selangor, which are all managed by the university. This article compiles available information regarding bats in UPM besides updating the available list of bat species from published and unpublished papers, and recent sampling using harp traps and mist nets. A total of 36 bat species were reported in UPM (12 species in UPMSC, 20 species in UPMKB and 21 species in AHFR). These bats were from seven families: Emballonuridae (three species), Hipposideridae (four species), Megadermatidae (one species), Nycteridae (one species), Pteropodidae (13 species), Rhinolophidae (two species) and Vespertilionidae (12 species). With regards to the conservation status, one species (Hypsugo macrotis) is categorised as 'Data Deficient', five species (Dyacopterus spadiceus, Kerivoula intermedia, K. minuta, Nycteris tragata, and Rhinolophus sedulus) as 'Near Threatened' and one species (Megaerops albicollis) categorised as 'Vulnerable' on the IUCN Red List of Threatened Species. The list of bat species provided, including those with conservation importance, can serve as a reference for campus management practices on its environmental activities especially in enhancing biodiversity value within the campus area.
\end{abstract}

Keywords: Chiroptera, checklist, urban, Sarawak, Ayer Hitam Forest Reserve.

\section{Introduction}

Bats (Order: Chiroptera) are fascinating mammals that hold an important place in our ecology. It represents about $50 \%$ of mammal species in tropical forests and $20 \%$ in the world (Lim et al., 2017). Chiroptera is the second largest order among mammals with more than 1,400 species from 21 extant families have been described worldwide (Simmons \& Cirranello, 2020). Bats can be divided into two suborders: Yinpterochiroptera (represented by seven families) and Yangochiroptera (represented by 14 families) (Springer, 2013). Globally, forested areas are the primary habitat that support the highest diversity of bat species (Russo et al., 2016). Bats are also among the most diverse mammals' group available in urban areas (van der Ree \& McCarthy, 2005; Jung \& Kalko, 2011). According to Francis (2019), Phillipps and Phillipps (2018) and Senawi and Norhayati (2021), there are about 143 species of bats found in Malaysia, representing $10 \%$ of the world's bats population. Recently, 113 bat species have been recorded in Peninsular Malaysia (eg: Khan et al., 2008; Lim et al., 2014; Francis, 2018; William-Dee, 2019) and 94 have been found in Malaysian Borneo (eg: Khan et al., 2007; Benda 2010; Phillipps \& Phillips, 2018; Khan et al., 2019; Mohd-Azlan et al., 2019; Senawi et al., 2020; Senawi \& Norhayati, 2021).

Universiti Putra Malaysia is one of the largest green campuses (Aris et al., 2018) in Malaysia. The uniqueness of UPM is that the campus consists of the main campus in Serdang 
Selangor in Peninsular Malaysia, and the Bintulu campus in Sarawak (UPMKB) on the island of Borneo. Apart from that, UPM has its own forest reserve, namely AHFR in Puchong, Selangor, and Nirwana Forest in UPMKB. Both forests are experimental and field stations for educational activities. Having a combination of various environments within the campuses, UPM preserves its green areas amid surrounding development that supports teaching and learning as well as research activities in the campuses. The green areas of UPM are important habitats for wildlife, including bats. Studies on bat communities in UPM have been carried out since 1999 by Jambari et al. focusing mainly on AHFR. Later, surveys were carried out, and were documented in either published or unpublished reports.

This paper aims to compile information on the diversity of bat species found throughout the three zones of UPM: UPMSC, UPMKB and AHFR from 1999 to 2020. It is hoped that this list will be useful especially to UPM, other scientific communities, government agencies, and non-governmental organizations to further support conservation strategies of bats.

\section{Materials and Methods}

The checklist of UPM bats presented here is based on data from published and unpublished reports, as well as current sampling data. Published data are those available through peerreviewed articles and short communications published in scientific journals and books. In contrast, unpublished data are based on diploma, bachelor and master's degree project reports (theses), abstracts and proceedings of conferences. Current sampling data refers to the latest studies conducted between 2019 and 2020 at UPM's Serdang Campus. Throughout this article, the following acronyms will be used in the text: Universiti Putra Malaysia Serdang Campus (UPMSC), Universiti Putra Malaysia Bintulu Sarawak Campus (UPMKB) and Ayer Hitam Forest Reserve (AHFR).

\section{Study Areas}

Universiti Putra Malaysia comprises of the main campus in Serdang, Selangor, a branch campus in Bintulu, Sarawak and a forest reserve in Puchong, Selangor. The main campus is located at $2^{\circ} 59^{\prime} 12.99^{\prime \prime} \mathrm{N}$ to $2^{\circ} 59^{\prime} 48.18^{\prime \prime}$ $\mathrm{N}$ and longitudes $101^{\circ} 42^{\prime} 22.33^{\prime \prime} \mathrm{E}$ to $101^{\circ}$ 42 ' 42.77" 42.77" E. UPMSC covers an area of 1245.056 ha, with approximately $45.8 \%$ covered with natural and ornamental vegetation, $51.2 \%$ is covered by agricultural crops, farms and grasslands habitat (Ideris, 2016) and the rest $(3 \%)$ are built up areas.

Universiti Putra Malaysia Bintulu Sarawak Campus (UPMKB) is one of the few green lungs still left in the Bintulu township (Norfahiah et al., 2012) situated 13 kilometers from the town $\left(3^{\circ} 12^{\prime} 31^{\prime \prime} \mathrm{N}, 113^{\circ} 05^{\prime} 52^{\prime \prime} \mathrm{E}\right)$, and is surrounded by an environment rich in flora and fauna, affirming UPM's mission to further explore the fields of agriculture and bioresources. The campus covers an area of 715.16 ha, with most areas (299.0 ha or $42 \%$ ) covered with greenery. A total of 37.3 ha has been assigned to the Tropical Rainforest Ecosystem Rehabilitation Project in Sarawak (Planted Forest), 25.5 ha planted with yemane; Gmelina arborea and acacia; Acacia mangium, 51.0 ha planted with oil palm; Elaeis guineensis, 25.0 ha planted with rubber trees; Hevea brasiliensis, 60.0 ha are reserved education forest (Nirwana Forest) and 100.2 ha consists of other fragmented secondary forests. Meanwhile, the rest of the area (416.16 ha) consists of existing and future development areas (Ong et al., 2008).

Situated in Puchong Selangor, Ayer Hitam Forest Reserve (AHFR) ( $3^{\circ} 00^{\prime} 28^{\prime} \mathrm{N}, 101^{\circ}$ $38^{\prime} 34$ ” E) covers an area of 1,248 ha. In 1996, Selangor's state government granted Universiti Putra Malaysia a lease to use the forest reserve for educational and research purposes (FaridahHanum, 1999) in forestry, wood science, as well as park and recreation management. AHFR is an important tropical lowland forest located in Selangor, Malaysia. It is the only forested area 
left in the Klang Valley besides the 10.6 ha of Bukit Nenas Forest Reserve that is threatened by rapid development.

\section{Bat Surveys}

Bat surveys (Figure 1) in UPM have been carried out at UPMSC from 2019 to 2020, which include the campus zone, faculties, institutes and colleges. Bat research in UPMKB was conducted between 2004 and 2010 by diploma, undergraduate and masters students to fulfill their project requirements (unpublished reports: Haziri \& Aijam Myustaqeen, 2004; Mazliawati \& Mc. Eddy, 2006; Mohd Zabidi \& Siti Hawa, 2007; Aminrulhisham \& Nurul Mardhiah, 2008; Mohd Hazlan \& Nurul Aidah, 2008; Edy Izzady \& Abu Rahman, 2008; Syed Ahmad Hazman \& Fatin Nazwa, 2008; Mohd Firdaus \& Mohd Farhan, 2008; Ritauddin \& Aminah, 2008; Norisah \& Hafizzuddin, 2008; Farah Awatif \& Nor Afiedatul Akmal,
2009; Muhammad Hafizuddin \& Sonetha, 2009; Murni \& Juliana, 2009; Mohd. Hafis \& Norasilah, 2009; Mohamad Syafiq \& Siti Sarah, 2010; Sasidhran \& Siti Nurfatin, 2010; Azema et al., 2009; and Ain Suriani et al., 2010). The study sites in UPMKB covered the campus zone, Planted Forest, Forestry Park and the reserve forest (Nirwana Forest). The campus zone comprises agricultural land, oil palm and rubber plantations, animal farm, mechanization workshops, administration and academic buildings, botanical park, as well as the Biopark and a waterfall area. As reported in the Annual Report UPM-Mitsubishi Forest Rehabilitation Project (Anon, 2019), the 3.4 ha planted forest area is planted with more than 352,694 indigenous forest trees from 127 species on five planting sites, with more than 100 research plots. The Nirwana Forest is a secondary forest that is mostly dominated by species from the family Dipterocarpaceae. Meanwhile, the forest park

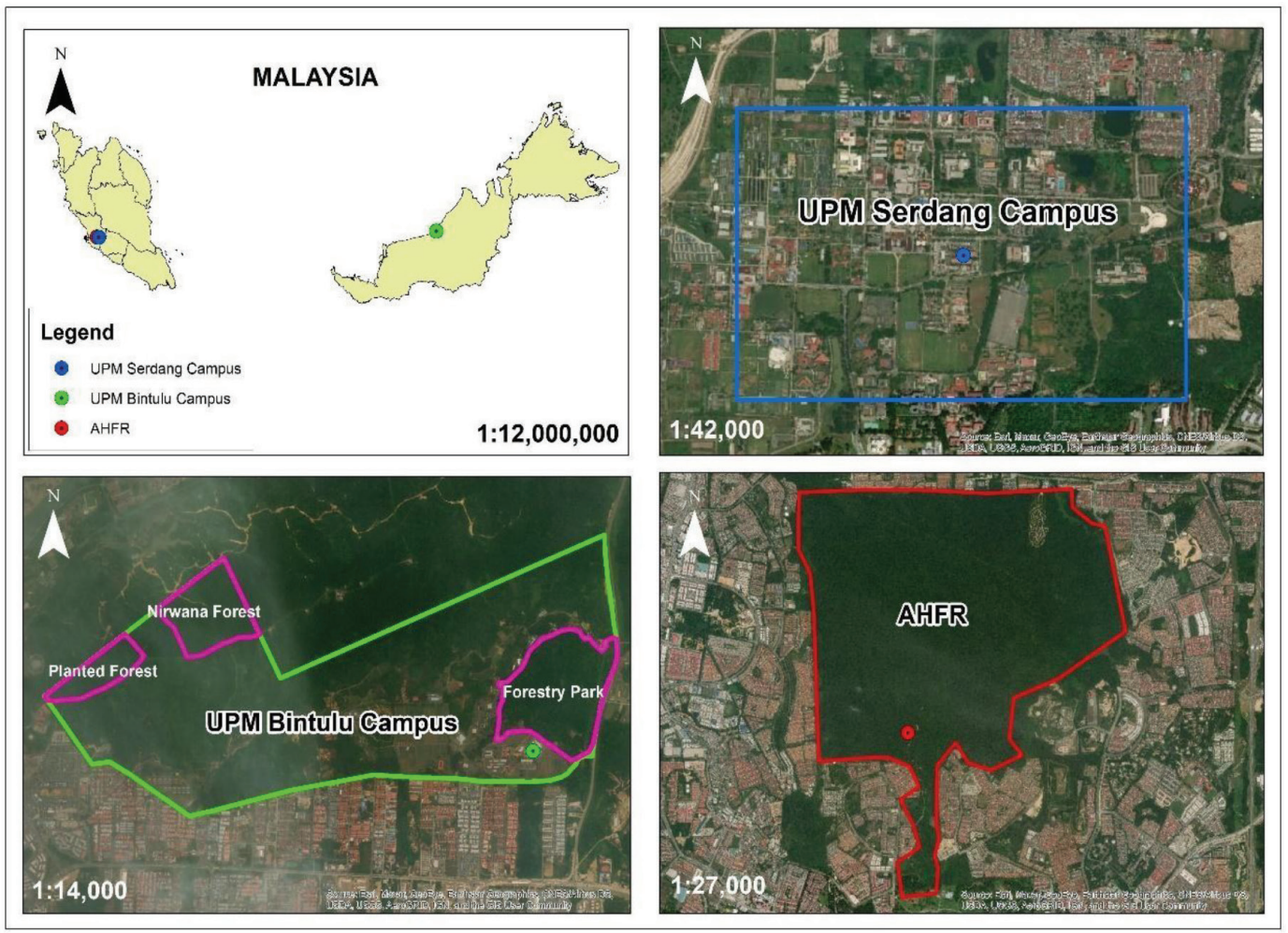

Figure 1: Maps indicating the locations and areas of UPM Serdang Campus (UPMSC), UPM Bintulu Sarawak Campus (UPMKB) and Ayer Hitam Forest Reserve (AHFR) 
consists of about 40 ha of lowland secondary forest. The forest park typically has less tree diversity due to logging. Openings created in the forest canopy allow sunlight to reach the forest floor, causing the area to be dominated by pioneer species, like ferns and Macaranga gigantea. Finally, bat surveys in the AHFR area began in 1999 to 2017 (Jambari et al., 1999; Mohd. Azlan et al., 2000; Ahmad Juffiry et al., 2015; Marina et al., 2017). The area covered compartments 12,13, 14 and 15 with different habitat points and landscapes such as river or stream, forest gaps, mid slopes and ridgetops. This lowland Dipterocarp forest covers a huge diversity in flora and fauna, including mammals, avians, reptiles, amphibians, fish and insects (Paiman \& Amat, 2007).

\section{Field Method}

The current survey was conducted in UPMSC from December 2019 to October 2020. Permission to conduct field research on bats was approved by the Department of Wildlife and National Parks (DWNP) Peninsular Malaysia (JPHL\&TN (IP): 100-34/1.24 Jld 16 (20)) and UPM IACUC (Institutional Animal Care and Use Committee) (UPM/IACUC/AUP-R040/2020). Bats were captured using mist nets, harp traps and hand nets (modified butterfly net). Three different environments were identified for the bat survey, namely i) foraging area ii) building roosting sites and iii) vegetation roosting sites.

For foraging areas, bats were captured by setting up four to eight mist nets (14 x $5 \mathrm{~m}$ with $2.5 \mathrm{~mm}$ mesh size and $9 \times 4 \mathrm{~m}$ with 3.0 $\mathrm{mm}$ mesh size) which were placed $0.5 \mathrm{~m}$ above ground (Shafie et al., 2011) and set at potential flight corridors or edge of remnants, near ponds, shelters or food sources. Mist nets supported by two aluminum poles were left open for about 12 hours (18:00h to 6:00h) and monitored at one-hour intervals. Nets were set for a period of two consecutive nights in each study area. Two- or four-bank harp traps (Francis, 1989; Jayaraj et al., 2011; Mohd-Hanif et al., 2015;
Yoh et al., 2020) were also deployed randomly for two consecutive nights per area based on the possibility of the bats roosting and anticipated flight paths.

For building roosting sites, all possible buildings around UPM were visited during the sampling period (Fagan et al., 2018). A standard inspection protocol was implemented in order to identify buildings that are actively used by bats. Direct observations of bats roosting were based on the presence of fresh guano, urine staining and feeding remains or rejected fruit pellets (Collins, 2016; Fagan et al., 2018). The surveys were conducted during the day from the exterior to the interior of the man-made structures, progressing from the ground floor to the higher floors. After the roosting sites were located, sampling of bats was conducted by setting up mist nets to cover possible routes that might be used by the bats to escape, and a modified hand-net (Tan et al., 1998) was used to directly capture the bats in any area inside the building.

All trees (ornamental and native) suspected of being used by any bat species were inspected and surveyed in the evening for vegetation roosting sites. All possible roosting sites were identified, and bats were captured by encircling the roost trees with mist nets (Digana et al., 2011) and shaping the mist nets into triangles. The triangle shape requires a long mist net $(14 \mathrm{x}$ 3 meters with $4 \mathrm{~mm}$ mesh size) and using three poles (6 meters long each) to set up. For trees with more than six meters in height, a triangle lift was used, where the mist nets were set up at a triangle shape frame, and the frame was elevated until the roosting level. This triangle lift requires three long mist nets ( $14 \times 3$ meters with $4 \mathrm{~mm}$ mesh size), three aluminum telescopic poles (6 meters each), three pulleys, three hauling ropes (nylon braided), three vertical anchor ropes (nylon braided), three diagonal anchor ropes (nylon braided), ten to twelve slider pins and three to four closing cords. The setting up was conducted in the morning of the sampling day, and nets were open from 18:00h to 24:00h. 


\section{Species Identification}

Standard external measurements of the captured bat (forearm length $(\mathrm{mm})$, body length $(\mathrm{mm})$ and tail $(\mathrm{mm})$ ) were taken using electronic digital vernier calipers and body weight $(\mathrm{g})$ was recorded using a Pesola spring balance (100 and $1,000 \mathrm{~g})$. In addition, other population data i.e. age (adult or juvenile), sex and reproductive status were also recorded (Ibrahim et al., 2013). Identification of species were made based on taxonomy key of bats for Peninsular Malaysia (Kingston et al. 2009), Medway (1983), Francis (2019), while those in Borneo were identified based on Payne et al. (1985), Borissenko and Kruskop (2003), Shazali et al. (2016), and Phillips and Phillips (2018). The "dental formula" as described by Francis (2019) was used in the identification of unidentified species based on the standard procedure. Voucher specimens were wet-preserved in $70 \%$ ethanol and housed at the Biology Department, Faculty of Science, UPM Serdang and the Department of Forestry Science, Faculty of Agricultural Science and Forestry, UPMKB. All other bats were released at the point of capture within 12 hours of capture. The conservation status of the bat species was confirmed against the IUCN (2020), PERHILITAN (2017), Wildlife Conservation Act (2010), and Wildlife Protection Ordinance (1998) lists for their conservation status.

\section{Results and Discussion}

Sources of valid records supporting the existence of bat species in the respective areas in UPM are presented in Table 1. Data collected throughout the study period, from 2004 to 2020, recorded 36 bat species (consisting of seven families: Emballonuridae (three species), Hipposideridae (four species), Megadermatidae (one species), Nycteridae (one species), Pteropodidae (13 species), Rhinolophidae (two species) and Vespertilionidae (12 species) (Table 1; Figure 2 ). This list represents approximately $26 \%$ of the total bat species recorded in Malaysia. From this record, 13 species were fruit bats, accounting for $36 \%$ of bat species recorded in UPM, with five species captured in both UPMSC and AHFR, while 10 species were found in UPMKB. On the other hand, 23 species $(66 \%)$ were found to be insect bats, with seven, 10 and 16 species recorded in UPMSC, UPMKB and AHFR respectively.

Cynopterus brachyotis, Eonycteris spelaea and Myotis muricola were the most common species recorded and found to be distributed in all three localities (UPMSC/UPMKB/AHFR). Some bat species were reported only in two localities: Scotophilus kuhlii (one species; UPMSC/AHFR); Cynopterus horsfieldii (one species; UPMSC/UPMKB); Hipposideros cervinus, Megaderma spasma, Penthetor lucasi, Rhinolophus sedulus, $R$. trifoliatus and Kerivoula papillosa (six species, UPMKB/ AHFR). Species recorded in a single locality were Saccolaimus saccolaimus, Taphozous longimanus, T. melanopogon, Rousettus amplexicaudatus, R. leschenaultii and Hypsugo macrotis (six species; UPMSC); Hipposideros diadema, Balionycteris maculata, C. sphinx, Dyacopterus spadiceus, Macroglossus minimus, Megaerops albicollis, K. minuta, Murina suilla, and Pipistresllus sp. (11 species; UPMKB); and Hipposideros bicolor, H. larvatus, Nycteris tragata, Balionycteris seimundi, Megaerops ecaudatus, $K$. intermedia, $P$. javanicus, Tylonycteris fulvida and T. malayana (nine species; AHFR).

\section{Pteropodidae}

Among the 13 species of fruit bats recorded, Cynopterus brachyotis and Eonycteris spelaea were the most common species captured and recorded in all localities. Cynopterus brachyotis was described as a common bat that can occupy a variety of habitats, including disturbed areas, orchards and plantations (Jayaraj et al., 2013; Khan et al., 2019; Mikail et al., 2017; Lim et al., 2019; Francis, 2019) indicating a relatively high ecological plasticity of the bat species (Benda, 2010). In UPMSC, it was observed to either roost singly or in small groups under leaves of trees and palms. 
Eonycteris spelaea is an important and most effective pollinator of many forest trees and commercial plant species, such as Durio spp. and Parkia spp. (Bumrungsri et al., 2008; 2009). It can always be found roosting in large colonies in caves, and forages in canopies of primary forest, gardens, mangroves and disturbed areas (Kingston et al., 2009; Acharya et al., 2015; Phillips \& Phillips, 2018). All records in UPM show that this species was successfully captured using mist nets set up near fruiting or flowering trees. This species can travel as far as $38 \mathrm{~km}$ to forage and feed on at least 31 species of plants (Bumrungsri et al., 2013).

The current survey recorded Cynopterus sphinx was captured in UPMKB campus zone and reserve forest (Planted Forest, Nirwana Forest and Forestry Park) (Mazliawati \& Mc. Eddy, 2006; Aminrulhisham \& Nurul Mardhiah, 2008; Mohd Firdaus \& Mohd Farhan, 2008; Eddy Izzady \& Abu Rahman, 2008; Azema et al., 2009). Compared to C. brachyotis, C. sphinx is larger with forearm length recorded between 65 and $69 \mathrm{~mm}$. However, this species is rarely found in Borneo (Phillipps \& Phillipps, 2018). Payne and Francis (2007) reported only one record from Borneo, in Central Kalimantan province. Other researchers, Kitchener and Maharadatunkamsi (1991) reported a male specimen from Gunung Kinabalu and Benda (2010) recorded the species in Sapulut, Sabah. 


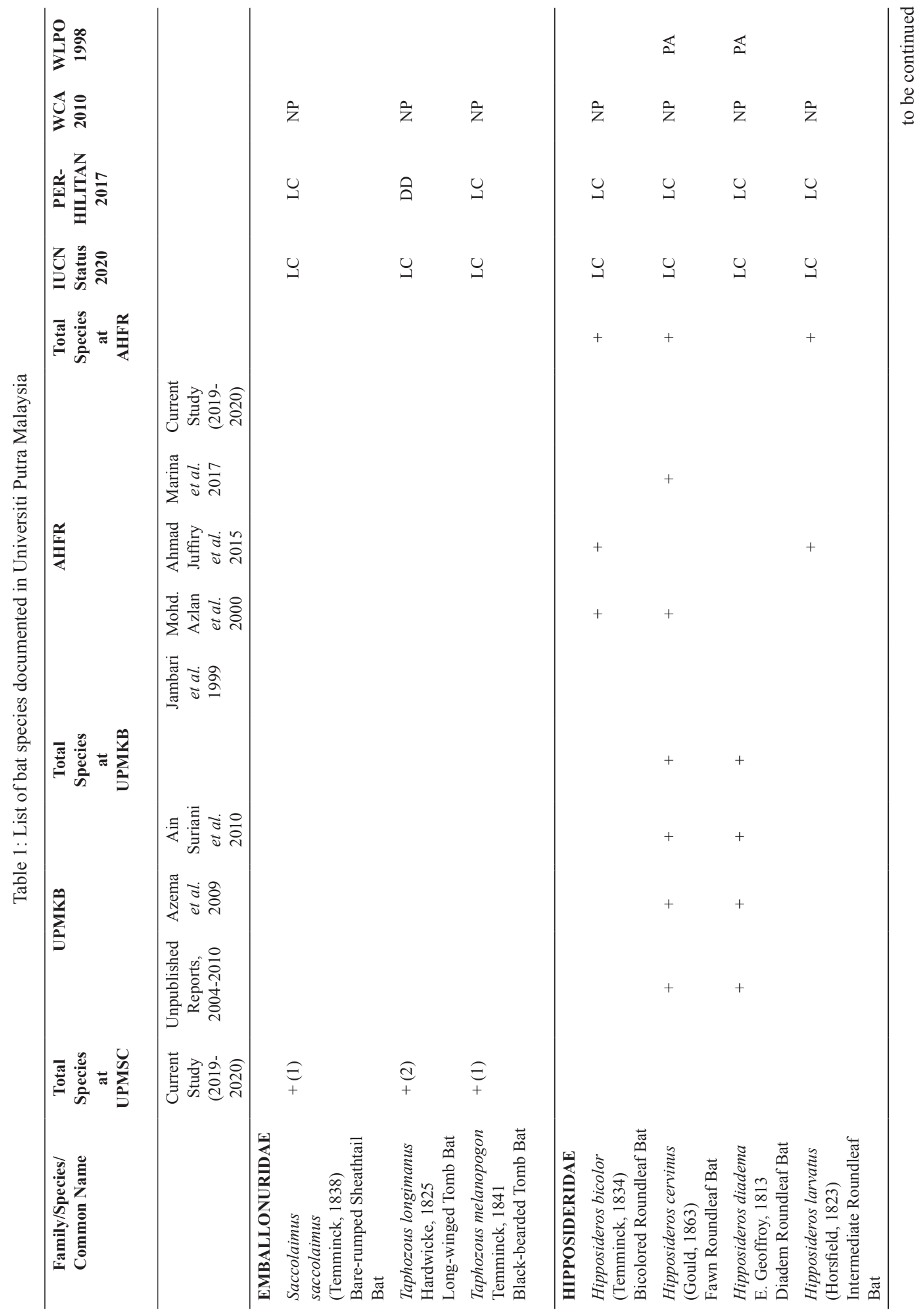

Journal of Sustainability Science and Management Volume 16 Number 7, October 2021: 237-259 


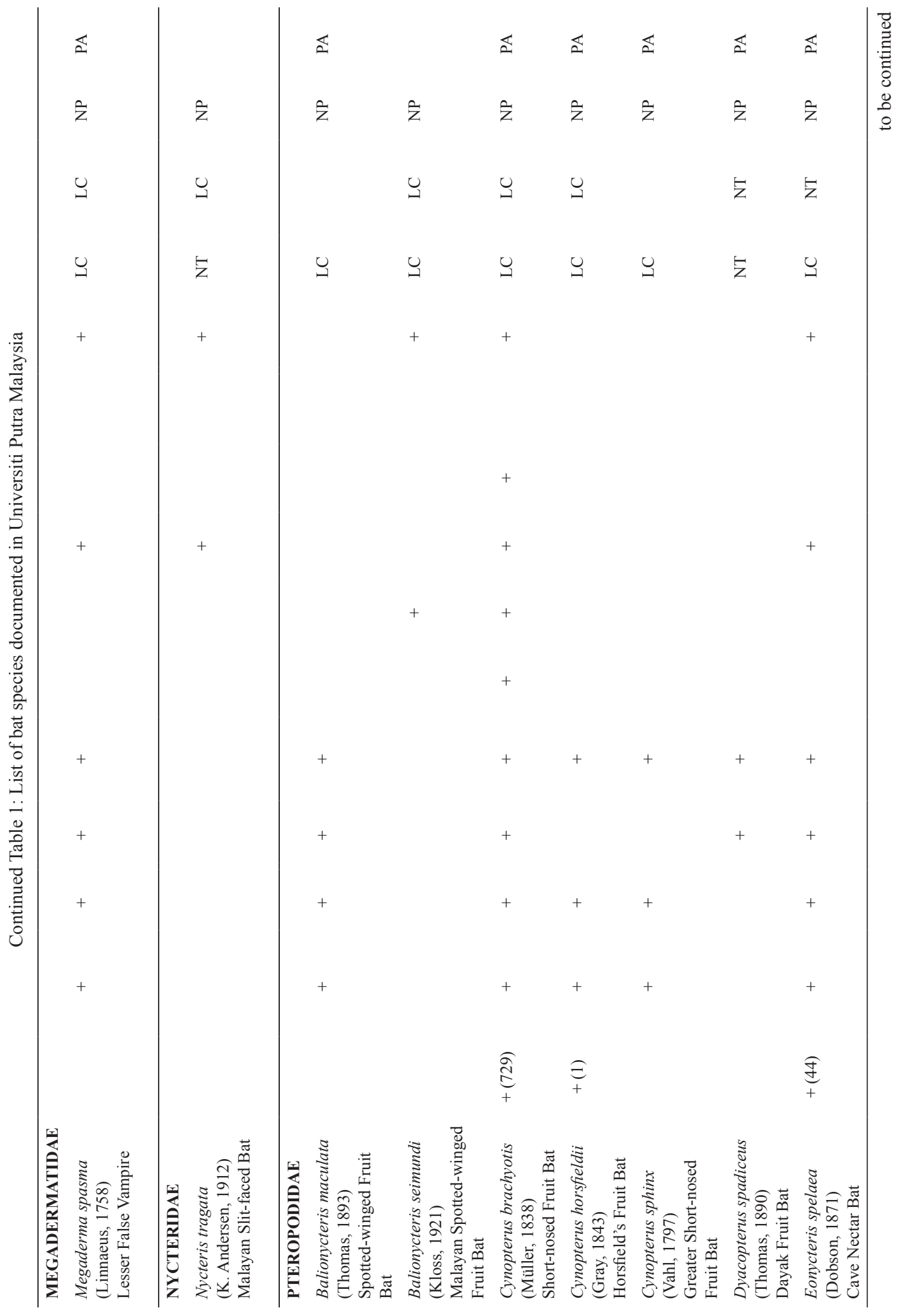

Journal of Sustainability Science and Management Volume 16 Number 7, October 2021: 237-259 


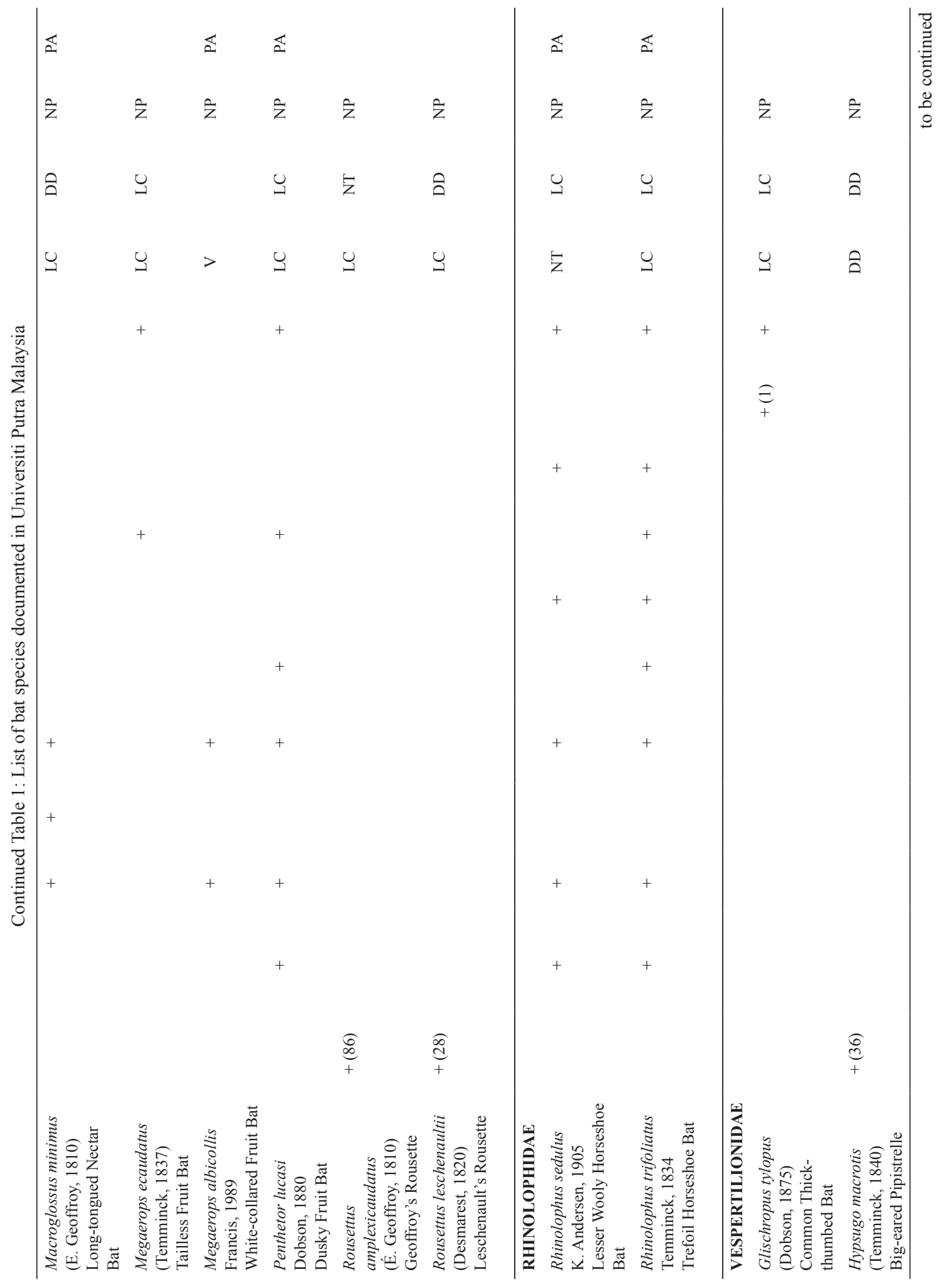

Journal of Sustainability Science and Management Volume 16 Number 7, October 2021: 237-259 


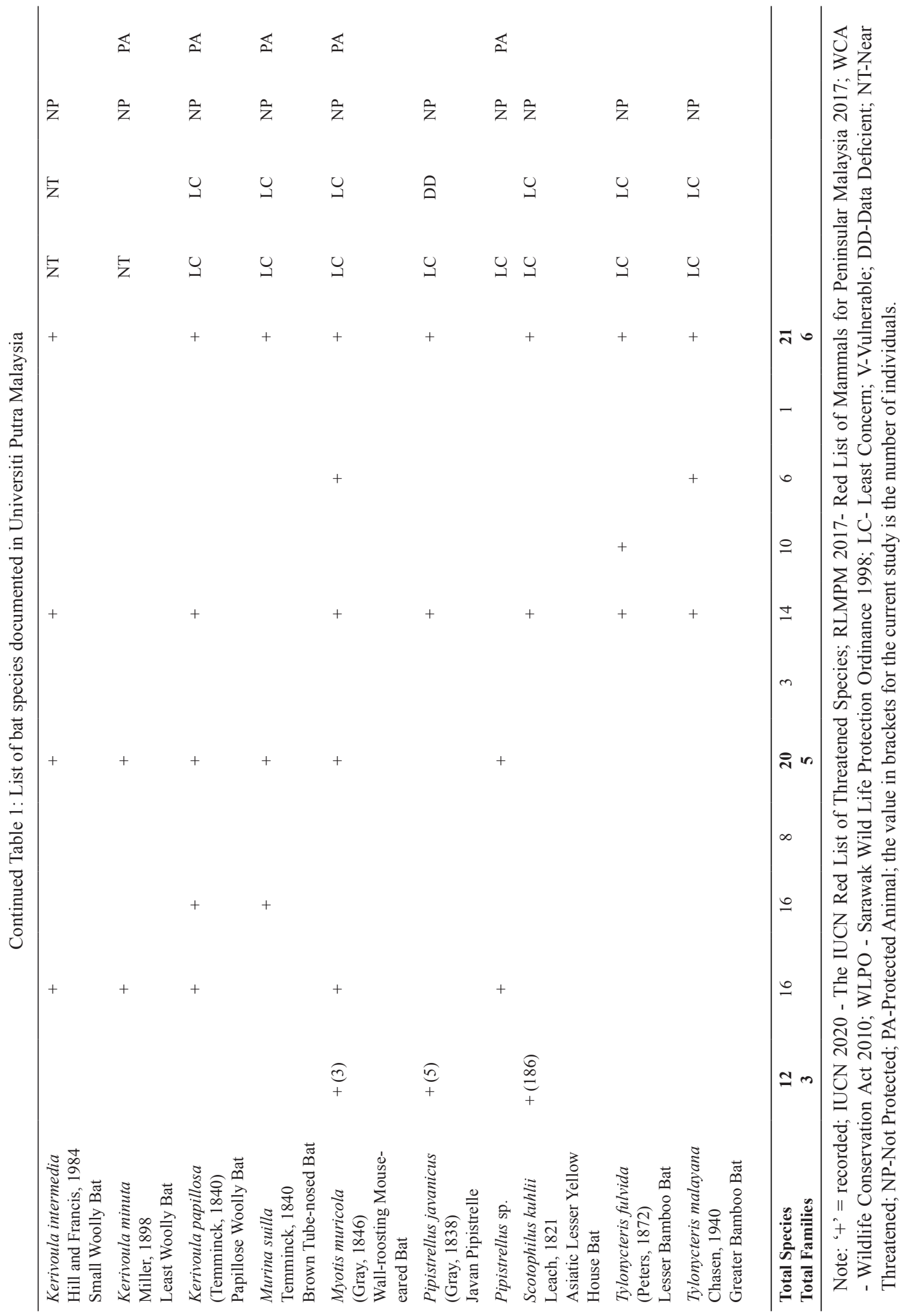

Journal of Sustainability Science and Management Volume 16 Number 7, October 2021: 237-259 

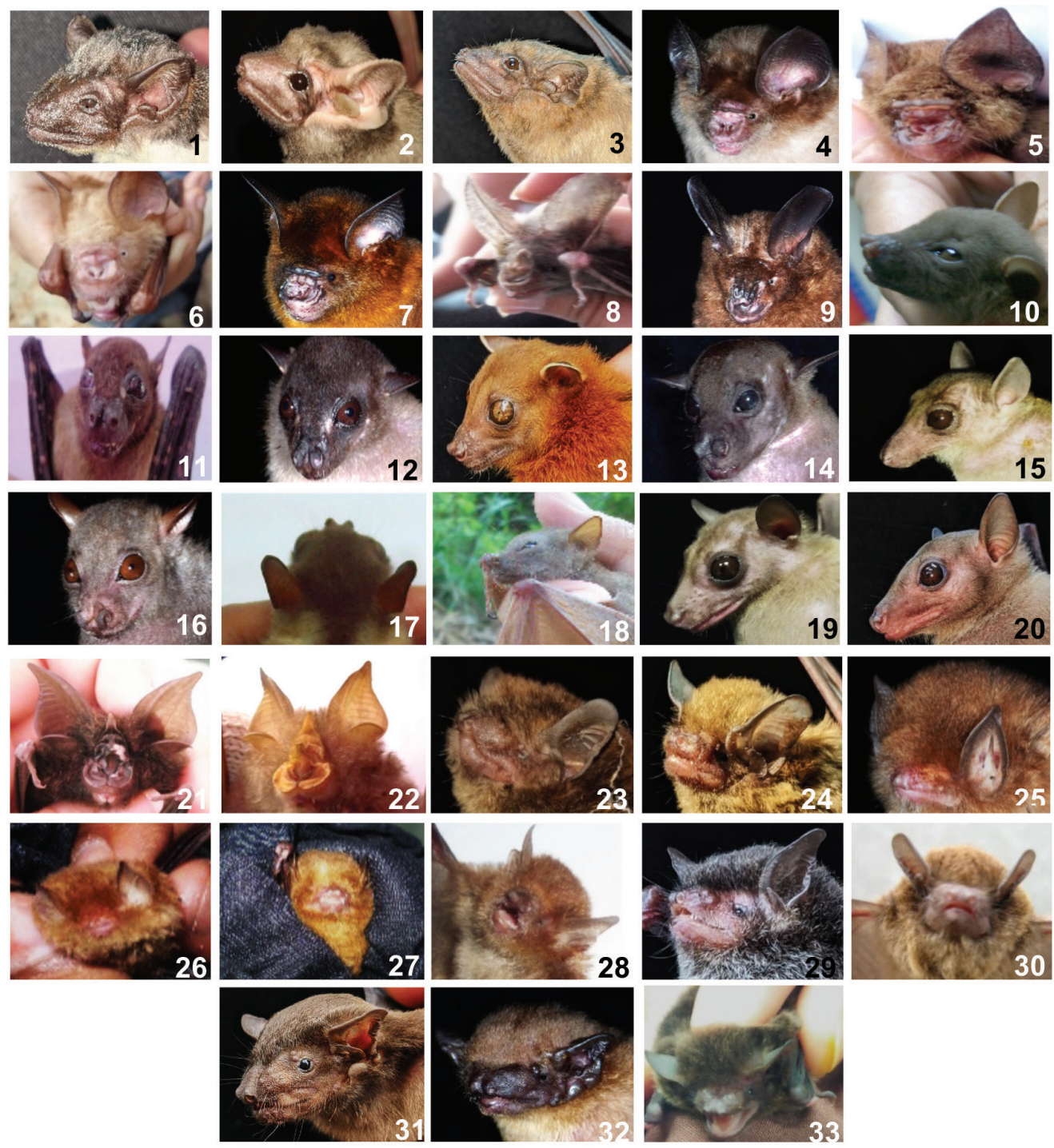

Figure 2: Bat species recorded in UPM. 1- Saccolaimus saccolaimus (C) Ahmad Badrul Amin, A. R.; 2- Taphozous melanopogon (C) Marina, M.T.; 3- Taphozous longimanus (C) Nur Farrazuin, J.; 4- Hipposideros bicolor (C) Senawi, J.; 5- Hipposideros cervinus (C) Nor Afiedatul, A.; 6- Hipposideros diadema (C) Juliana, N.; 7- Hipposideros larvatus $\mathbb{C}$ Senawi, J.; 8- Megaderma spasma $\mathbb{C}$ Nor Afiedatul, A.; 9- Nycteris tragata (C) Senawi, J.; 10-Aethelops aequalis (C) Mohd Firdaus, K.; 11- Balionycteris maculata (C) Mohd. Hafis, N.; 12- Balionycteris seimundi $\mathbb{C}$ Senawi, J.; 13-Cynopterus brachyotis $\mathbb{C}$ Marina, M.T.; 14- Dyacopterus spadiceus (C) Senawi, J.; 15- Eonycteris spelaea $($ ) Ahmad Badrul Amin, A. R.; 16- Megaerops ecaudatus (C) Senawi, J.; 17- Megaerops albicollis (C) Azema, I.; 18- Penthetor lucasi (C) Muhamad Syafiq, C. S.; 19-

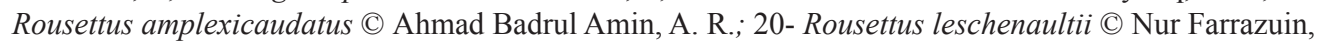
J.; 21- Rhinolophus sedulus (C) Farah Awatif, K.; 22-Rhinolophus trifoliatus $($ C Murni, S.; 23-Glischropus tylopus (C) Marina, M.T.; 24- Hypsugo macrotis (C Nur Farrazuin, J.; 25- Kerivoula intermedia (C Senawi, J.; 26- Kerivoula minuta $($ Mohd Firdaus, K.; 27- Kerivoula papillosa $@$ Mohd Firdaus, K.; 28- Murina suilla $($ C) Azema, I.; 29- Myotis muricola $($ C) Ritauddin, A. R.; 30- Pipistrellus sp. (C) Mohd. Hazlan, A.R.; 31Scotophilus kuhlii (C) Ahmad Badrul Amin, A. R.; 32- Tylonycteris fulvida (C) Senawi, J.; and 33- Tylonycteris malayana $($ ) Noraini Che, A. N. 
Ain Suriani et al. (2010) recorded a single individual of the Dayak fruit bat (Dyacopterus spadiceus) in the oil palm plantation of UPMKB. A single individual of this species was also captured at Gunung Mulu by Shazali et al. (2016). Phillipps and Phillipps (2018) reported the species in the lowland area of Sarawak, and sometimes found it in the upper canopy while feeding on fruiting figs. The species is rarely caught in the understorey traps, except when they come down to drink or feed on lower fruit trees (Mohd-Ridwan et al., 2018). This species is listed as a near threatened species under the IUCN (IUCN, 2020) due to the decline of lowland rainforests.

Two individuals of the white collared fruit bat (Megaerops albicollis) (one male adult and one male juvenile) were captured using a 4-shelf mist net in 2009 at the Nirwana Forest of UPMKB. The findings have been published in the $3^{\text {rd }}$ Regional Conference on Natural Resources in the Tropics (NRTrops3) in Kuching, Sarawak, in 2009 (Azema et al., 2009). Shazali et al. (2016) reported on a single individual of the same species caught using high-net trap in Gunung Mulu National Park in Sarawak. It is noted that the first record of the species was in Tasek Merimbun in Brunei during a field study conducted in 1983-84 (Haji Idris, 2012; Payne, 1985; Philips \& Phillips, 2018). According to Matthew et al. (2006), this species is categorised as a below canopy frugivore. Therefore, the species may only be sampled at ground level if they commute to roost or forage in the understorey. At Krau Wildlife Reserve, Pahang, this species is known to forage at the canopy level (Kingston et al., 2006). Megaerops albicollis is listed as vulnerable due to the shrinking lowland rainforest area (Francis, 2019) and categorised as rare by Phillipps and Phillipps (2018).

Two species of Rousettus have been recorded in UPMSC, which were captured near a mango tree at Kolej Sepuluh, along a pond at Ladang Humprey, and few foraging areas at Bukit Ekspo, Faculty of Forestry and Environment and Faculty of Biotechnology. Previously, $R$. leschenaultii has only been recorded in Wang Kelian State Park in Perlis (Jayaraj et al., 2013) and Batu Caves in Selangor (Moseley et al., 2012). This data adds to the current distributional record of $R$. leschenaultii in Peninsular Malaysia.

The other six fruit bat species (Balionycteris seimundi, B. maculata, Cynopterus horsfieldii, Macroglossus minimus, Megaerops ecaudatus, and Penthetor lucasi) are commonly and widely distributed throughout Peninsular Malaysia (Medway, 1983; Matthew et al., 2006; Jayaraj et al., 2013; Lim et al., 2019) and Borneo (Payne et al., 1985; Andrew et al., 2002; Benda, 2010; Struebig et al., 2012; Phillipps \& Phillipps, 2018; Khan et al., 2019).

\section{Emballonuridae}

Three species of Emballonuridae were recorded only in UPMSC. Bare-rumped sheathtail bat (Saccolaimus saccolaimus) was caught in UPMSC near the guest-housing area. This bat has been found in houses, hollow trees and rock crevices, and forages high above the ground (Francis, 2019). A single black-bearded tomb bat (Taphozous melanopogon) was accidently caught at UPM's Main Hall building attic, trapped in a mist net which was set up as a bat control measure in the building. The species has been reported to roost in buildings in urban areas (Kingston et al., 2009). Other than that, two male long-winged tomb bats (T. longimanus) were captured in palm trees (Livistona chinensis) at a college residential area and faculty site. Taphozous longimanus has been reported to roost in buildings, caves, tree hollows, crowns of palm trees and among rocks (Francis, 2019; Lim et al., 2017). For identification purposes, T. longimanus possesses a glandular pouch under the chin and metacarpal pouch, while $S$. saccolaimus and T. melanopogon possess either a glandular pouch or a metacarpal pouch, respectively (Francis, 2019). According to Krutzsch (2000), glandular pouch or glandular scent organ found on some emballonurids is a secondary sexual characteristic commonly found in males. It is used to mark territory, as a defense mechanism and for breeding purposes. 


\section{Hipposideridae}

Four species namely Hipposideros bicolor, $H$. cervinus, $H$. diadema and $H$. larvatus were recorded (see Table 1). Hipposideros bicolor and $H$. larvatus were recorded by Mohd. Azlan et al. (2000) and Shaidin et al. (2015). These bats were captured in AHFR in a low number of individuals. Higher number of captures has been reported in other lowland mixed dipterocarp tropical rainforests across Peninsular Malaysia (Lim et al., 2019; Jayaraj et al., 2013). Hipposideros cervinus was captured at UPMKB's Planted Forest (Farah Awatif \& Nor Afiedatul Akmal, 2009) and Campus Zone (fruit orchard) (Mazliawati \& Mc. Eddy, 2006) area. In AHFR, this species was captured using both harp traps and mist nets (Mohd. Azlan et al., 2000; Marina et al., 2017). Meanwhile, one $H$. diadema was captured at the Planted Forest in UPMKB (Mohd Hazlan \& Nurul Aidah, 2008) and four $H$. larvatus were recorded only at AHFR (Ahmad Juffiry et al., 2015). Although these four species are known to roost in large colonies, such as in limestone caves (Kingston et al., 2009), H. cervinus being a dominant caveroosting species (Struebig et al., 2012), was the most recorded species in both UPMKB and AHFR.

\section{Megadermatidae}

Lesser false vampire (Megaderma spasma) was the only species recorded under this family. This species was first recorded with only one individual captured in 2009 at the Planted Forest and fruit orchard in UPMKB (Farah Awatif \& Nor Afidatul Akmal, 2009; Azema et al., 2009; Ain Suriani et al., 2010) and at AHFR in 2015 (Ahmad Juffiry et al., 2015) respectively. In Peninsular Malaysia, they roost in a small group in caves, tunnels or hollow trees (Kingston et al., 2009) while Lim et al. (2019) reported two individuals captured in the lowland tropical forests with rock boulders or within limestone areas.

\section{Nycteridae}

One individual of the Malayan slit-faced bat (Nycteris tragata) was captured at AHFR (Ahmad Juffiry et al., 2015). Coastal or lowdisturbance inland forests caves or rock boulders are suitable areas for this species (Lim et al., 2019). The bat species is primarily a forest species (Kingston et al., 2009) and is classified as near threatened as the population is depleting (IUCN, 2020).

\section{Rhinolophidae}

Two bats species, Lesser wooly horseshoe bat (Rhinolophus sedulus) and Trefoil horseshoe bat (R. trifoliatus) were both recorded in the Planted Forest and the Nirwana Forest of UPMKB and AHFR (Norisah \& Hafizuddin, 2007; Syed Ahmad Hazman \& Fatin Najwa, 2008; Mohd Hazlan \& Nurul Aidah, 2008; Farah Awatif \& Nor Afiedatul Akmal, 2009; Azema et al., 2009; Jambari et al., 1999; Mohd. Azlan et al., 2000; Ahmad Juffiry et al., 2015; Marina et al., 2017). According to Matthew et al. (2006), R. sedulus is a narrow space insectivore and is categorised as near threatened due to a reduction in the lowland rainforests (Francis, 2019). The capture of the species in the Planted Forest of UPMKB may be related to trees that are planted closely together in the area. Rhinolophus trifoliatus is often caught in the understorey of the primary forest where it sometimes roosts under large leaves (Shirley et al., 2005). Other studies reported finding the species near established paths in the forest or forest gaps caused by fallen trees (Shazali et al., 2016; Khan et al., 2019).

\section{Vespertilionidae}

A total of 12 species were recorded, indicating the species' ability to adapt to different habitats in several localities. Newly recorded in AHFR in 2020, the common thick-thumbed bat (Glischropus tylopus) was caught in a mist net near bamboo plants in Compartment 15. This species was found roosting in small groups in bamboo stems or dead or damaged bamboo (Kofron, 1994; Lim et al., 2019). 
In the current study in UPMSC, we added a new location for the distribution of the big-eared pipistrelle (Hypsugo macrotis) for Malaysia, which is listed under the Data Deficient category. This species was spotted inhabiting the tighttop end corners of the roofing (range of 1 to 14 individual/s) and behind a blue pin-up bulletin board (4 individuals) at the Centre of Foundation Studies for Agricultural Science in UPMSC. Other locations where the species was spotted in UPMSC are the Faculty of Science, Faculty of Modern Language and Communication, Faculty of Forestry and Environment, and Faculty of Engineering. Six individuals of the species were captured at their roosting tree (Livistona chinensis) living together with Scotophilus kuhlii, but at a different side of the dry palm fronds. This species was first recorded in Selangor by Medway (1978) and then by Francis and Hill (1986). In 2016, Lim et al. reported finding this species at a school in the center of Seremban city.

Small woolly bat (Kerivoula intermedia) was recorded in both UPMKB (Planted Forest and Nirwana Forest) (Norisah \& Hafizuddin, 2007) and AHFR (Mohd. Azlan et al., 2000), while the least woolly bat (K. minuta), which is Borneo's smallest bat (Phillipps \& Phillipps, 2018), was recorded only in Nirwana Forest of UPMKB (Syed Ahmad Hazman \& Fatin Nazwa, 2008). The small woolly bat inhabits the understorey of tall lowland forests, and has been reported in low abundance by Christine et al. (2013) in six forest reserves in Peninsular Malaysia. Meanwhile, the least wooly bat prefers the understorey of lowland rainforest (Francis, 2019) and have been found at Mount Penrisen in Sarawak by Jayaraj et al. (2006). Previous studies indicated that $K$. intermedia is distributed widely throughout Borneo (Payne and Francis 1985) while K. minuta is rare (Jayaraj et al., 2006). Both species are listed as Near Threatened conservation status (IUCN, 2020). The papillose wooly bat (K. papillosa) was found in both forested areas of UPMKB (Planted Forest and Nirwana Forest) (Mohd Zabidi \& Siti Hawa, 2007; Mohd. Hazlan \& Nurul Aidah, 2008; Syed Ahmad \& Fatin Nazwa,
2008) and AHFR (Mohd. Azlan et al., 2000). The papillose wooly bat prefers to forage in the understorey of lowland rainforests and roosts in small holes of living trees, and sometimes found inside bamboo cavities (Francis, 2019). Forest specialists from the genus Kerivoula mainly forage in dense vegetation (Mohd-Ridwan et al., 2018).

The brown tube-nosed bat (Murina suilla) was recorded in the Planted Forest of UPMKB (Mohd Zabidi \& Siti Hawa, 2007; Azema et al., 2009) and this species is a common bat found in forested areas throughout Borneo (Phillipps \& Phillipps, 2018). Murina is among the rare species of vespertilionids, but has been recorded throughout Southeast Asia (Medway, 1983; Tingga et al., 2012).

The Asian whiskered myotis (Myotis muricola) was captured in UPMKB Campus Zone (Ritauddin \& Aminah, 2008) and in Compartment 15 of AHFR (Mohd. Azlan et al., 2000 \& Marina et al., 2017). It has been captured using mist nets near bamboo plots (Jayaraj et al., 2012), in open areas, heath forest, peat swamps, streams and rivers near a forest, and agricultural plots (Francis, 2008; 2019). In UPMSC, a single bat was found roosting in young rolled-up banana leaves at the staff housing area and nearby Serumpun College. In Singapore, similar findings on M. muricola roosting has been reported by Baker (2017), where the species was found in furled young leaves of ornamental banana plants in a garden of a concrete apartment building complex in a suburban area. They found three and eight bats in two different tubular leaves. Happold and Happold (1990) discussed that furled banana leaves provide suitable roosting conditions for banana bats as: (i) the leaves are available perennially, (ii) the humid microclimate within the furled leaves due to plant transpiration limits dehydration during the day and (iii) intraspecific competition for suitable leaves is limited.

Only two Javan pipistrelle (Pipistrellus javanicus) individuals were captured using the harp traps in AHFR (Mohd. Azlan et al., 2000) and four individuals were captured using a mist 
net set up under the clay-tiled roof at the gazebo of Kolej Kedua, UPMSC. This species has been recorded in a wide variety of habitats, including mangroves, lowland and hill forests, towns and rubber plantations, and in tree ferns, fallen logs and caves (Kingston et al., 2006; Francis, 2019). In Peninsular Malaysia, the species has also been reported in Perak and Pulau Pinang (Medway, 1969); Pahang (Kingston et al., 2009; Hill, 1967); and Kedah (Norsham et al., 1999). Only one individual of Pipistrellus sp. was captured at the Planted Forest of UPMKB (Mohd. Hazlan \& Nurul Aidah, 2008) but identification up to the species level was not done.

Asiatic lesser yellow house bat (Scotophilus kuhlii) was the second highest capture recorded at UPMSC. This bat was trapped in mist nets set up at foraging area or roosting trees, and found roosting either as a big colony in palm trees (Livistona chinensis) or roosting together with other species, such as Cynopterus brachyotis or
Hypsugo macrotis. A single individual of this species was captured in AHFR by Mohd. Azlan et al. (2000). The bats are known to inhabit a wide variety of habitats, including forested and urban areas (Jayaraj et al., 2016; Francis, 2019; Lim et al., 2019) and can be found roosting in large colonies in the roofs of houses, old and abandoned buildings, and in the crowns of palm trees in gardens (Kingston et al., 2009; Nuratiqah et al., 2017).

On the other hand, two species of Tylonycteris bat, both lesser bamboo bat (Tylonycteris fulvida, formerly known $T$. pachypus) and greater bamboo bat (T. malayana, formerly T. robustula) were captured in AHFR (Mohd. Azlan et al., 2000). These bats prefer using bamboo internodes as roosting sites (Francis, 2019; Tingga et al., 2020) and depend on bamboo stands for survival. These species are now threatened by deforestation (Tingga et al., 2020).

Table 2: Number of individuals for each bat species from the current study

\begin{tabular}{cccc}
\hline \multicolumn{1}{c}{ Family } & Species & $\begin{array}{c}\text { Individuals } \\
\text { Captured }\end{array}$ & $\begin{array}{c}\text { Relative } \\
\text { Abundance (\%) }\end{array}$ \\
\hline Emballonuridae & Saccolaimus saccolaimus & 1 & 0.09 \\
& Taphozous longimanus & 2 & 0.18 \\
& Taphozous melanopogon & 1 & 0.09 \\
\hline Pteropodidae & Cynopterus brachyotis & 729 & 64.97 \\
& Cynopterus horsfieldii & 1 & 0.09 \\
& Eonycteris spelaea & 44 & 3.92 \\
& Rousettus amplexicaudatus & 86 & 7.66 \\
\multicolumn{1}{c}{ Vespertilionidae } & Rousettus leschenaultii & 28 & 2.50 \\
& Hypsugo macrotis & 36 & 3.21 \\
& Myotis muricola & 3 & 0.27 \\
& Pipistrellus javanicus & 5 & 0.45 \\
Total Individuals & Scotophilus kuhlii & 186 & 16.58 \\
Number of Species & & $\mathbf{1 1 2 2}$ & 100 \\
Number of Families & & $\mathbf{1 2}$ & \\
Diversity, H' & $\mathbf{3}$ & \\
Evenness, J' & & $\mathbf{1 . 1 7 4}$ & \\
\hline
\end{tabular}


A total of 1,122 bat individuals comprising 12 species from three families have been recorded in UPMSC. The most abundant bat species in this survey was $C$. brachyotis $(\mathrm{n}=$ $729,64.97 \%$ ) followed by Scotophilus kuhlii ( $\mathrm{n}=186,16.58 \%)$ and $R$. amplexicaudatus (n $=86,7.66 \%$ ). Three species were captured as singletons: $S$. saccolaimus, Taphozous melanopogon and C. horsfieldii. The diversity index, H' for bats in UPMSC was 1.174 but it was not evenly distributed $\left(\mathrm{J}^{\prime}=0.473\right)$. However, in terms of species diversity, UPMSC has a low number of species compared to UPMKB and AHFR (Table 2).

In Universiti Malaysia Terengganu (UMT), formerly known as Kolej Universiti Sains dan Teknologi Malaysia (KUSTEM), species diversity seems to be lower than UPMSC, and it has been reported that UMT has four species from two families (Widad \& Wong, 2013). Three species were frugivorous bats from the family Pteropodidae, which are Cynopterus brachyotis, C. horsfieldii, and Eonycteris major, while the one insectivorous species was from the family of Vespertilionidae, which is Kerivoula papillosa (Widad \& Wong, 2013). They reported three fruit bat species $(C$. brachyotis, $C$. horsfieldii and Eonycteris major) and one insect bat species, (K. papillosa) were captured, with $C$. brachyotis being the highest capture, similar to what was reported in UPMSC. Various sampling techniques and locations surveyed, especially possible roosting trees and buildings, contributed to 12 bats species recorded in UPMSC.

A total of 20 bat species were recorded in UPMKB (Azema et al., 2009 \& Ain Suriani et al., 2010) representing $21 \%$ of a total 94 species of bats recorded in Borneo. Among the three capture areas, Azema et al. (2009) reported the Planted Forest showed a higher number of bat species than the Nirwana Forest and Forestry Park. Flowering and fruiting trees are the food sources that attract animals to the Planted Forest. The Nirwana Forest recorded the second highest bat species after the Planted Forest. The close distance between the Nirwana Forest and Planted Forest probably influenced the number of bat species captured. The Forestry Park recorded the lowest number of species caught. Fewer big trees in the Forestry Park probably affected the availability of the bats' food source and roosting site (Marina et al., 2017). Studies by Gaisler et al. (1998) and Lesinski et al. (2000) found that tree cover positively influenced the overall pattern of species richness of bat communities. Castro-Luna et al. (2007) stated that certain bat species select specific succession stages. This selection is positively or negatively correlated with the canopy cover and floristic composition of the vegetation stand. Martínez-Ferreira et al. (2020) reported that although several bat species can find resources in the secondary forests, they continue to depend on the resources available in old growth forests, which favor great diversity and abundance for bats.

When compared to UPMSC and UPMKB, the diversity of insectivorous bat species recorded in AHFR is higher, with 16 species recorded and one new species currently added to the list of bats in AHFR. However, Mohd. Azlan et al. (2000) previously reported that the diversity of bats species in AHFR appeared to be relatively low in comparison to other forest reserves in Peninsular Malaysia: Krau Wildlife Reserve, Pahang (32 species, Zubaid, 1993; 69 species, Kingston et al., 2009); Temengor Forest Reserve, Perak (41 species, Ratnam et al., 1995); and Ulu Gombak Forest Reserve, Pahang (57 species, Sing et al., 2013). The species diversity at AHFR is comparable to that reported in Bangi Forest Reserve (13 species, Zubaid, 1993); Fraser Hill Forest Reserve (16 species, Mohd-Hanif et al., 2015) and EndauKota Tinggi Forest Reserve (17 species, MohdHanif et al., 2015) or slightly better to EndauKluang Forest Reserve (9 species, Mohd-Hanif et al., 2015), Sungai Dusun Forest Reserve (10 species, Mohd-Hanif et al., 2015), Tasek Bera Forest Reserve (10 species, Mohd-Hanif et al., 2015), and Lata Bujang Forest Reserve (11 species, Mohd-Hanif et al., 2015). 


\section{Conclusion}

Availability of different habitats (including forested, agricultural, and urban areas) has greatly contributed to UPM's ability in accommodating different species of bats. This paper records 36 bat species in UPM and its forest reserves revealing common species and several relatively rare forms, such as Cynopterus sphinx, Dyacopterus spadiceus, Megaerops albicollis, Rhinolophus sedulus, Nycteris tragata, Hypsugo macrotis, Kerivoula intermedia, and $K$. minuta. Consistent and continuous monitoring and surveys should be implemented in all three localities of UPM to update and record species diversity and distribution of bats for future tracking. Future monitoring of species, particularly those listed as Vulnerable, Near Threatened and Data Deficient should be conducted persistently. Scale enhancement of habitats or landscapes must be introduced to increase bats diversity and prioritizing protection of suitable habitats within the vicinity of bats' roosting sites can be a good practice for the management and conservation of bat diversity.

\section{Acknowledgements}

The authors are grateful to Universiti Putra Malaysia for the approval and support in conducting the surveys throughout the years. Special thanks to Dr. Zamri Rosli and Dr. Roland Kueh Jui Heng for providing some insights on UPMKB forests. Our sincere thanks to all students and support staff for their involvement, enthusiasm and commitment throughout the data collection and documentation process. Lastly, a sincere thanks to Mr. Muhammad Nasri Rifin for helping us conduct research in UPMSC area with tree inspection, setting up mist nets at roosting trees, and providing the personal protective equipment (PPE) and assistance in the inspection of high places.

\section{References}

Acharya, P. R., Racey, P. A., Sotthibandhu, S., \& Bumrungsri S. (2015). Home-range and foraging areas of the dawn bat Eonycteris spelaea in agricultural areas of Thailand. Acta Chiropterologica, 17(2), 307-319.

Ahmad Juffiry, S. A, Ebil. Y., \& Mohamed Zakaria, H. (2015). Diversity of fauna species in Ayer Hitam Forest Reserve, Selangor, Malaysia. The Malaysian Forester, 78(1 \& 2), 97-114.

Ain Suriani A. A., Azema, I., \& Marina, M. T. (2010). Ectoparasite on bat species in selected of Universiti Putra Malaysia Bintulu Sarawak Campus. Proceeding of the $11^{\text {th }}$ Symposium for the Malaysian Society of Applied Biology 2010.

Almeida, F. C., Simmons, N. B., \& Giannini, N. P. (2020). A species-level Phylogeny of old world fruit bats with a new higher-level classification of the Family Pteropodidae. American Museum Novitates, (3950), 1-24. https://doi.org/10.1206/3950.1

Aminrulhisham, K., \& Nurul Mardhiah, A. R. (2008). Kepelbagaian spesies kelawar pemakan buah di Hutan Nirwana, Universiti Putra Malaysia Kampus Bintulu. Unpublished Report, Universiti Putra Malaysia Bintulu Sarawak Campus.

Andrew, A. A., Maklarin, L., \& Hall, L. (2002). Preliminary survey of bats of the Crocker Range National Park Sabah, Malaysia. ASEAN Review of Biodiversity and Environment Conservation (ARBEC), 1-5.

Anon. (2019). Annual Report UPM-Mitsubishi Forest Rehabilitation Project. Unpublished Report, Bintulu Sarawak.

Aris, A. Z., Ponrahono, Z., Ishak, M. Y., Zamaruddin, N. H., Noordin, N. K., Varatharajoo, R., \& Ideris, A. (2018). Green@Universiti Putra Malaysia: Cultivating the green campus culture. E3S Web of Conferences, 48, 02004.

Azema, I., Norfahiah, M., Marina, M. T., \& Zakaria, M. (2009). Survey on bats species in Universiti Putra Malaysia Bintulu Campus, Sarawak. Proceedings of the $3^{\text {rd }}$ Regional Conference on Natural Resources in the Tropics (NRTrop3).

Baker, N. (2017). Whiskered myotis roosting at Upper Thomson. Singapore Biodiversity Records, 2017, 133-134. 
Benda, P. (2010). On a small collection of bats (Chiroptera) from western Sabah (North Borneo, East Malaysia). Vespertilio, 13-14, 45-76.

Bumrungsri, S., Harbit, A., Benzie, C., Carmouche, K., Sridith, K., \& Racey, P. A. (2008). The pollination ecology of two species of Parkia in southern Thailand. Journal of Tropical Ecology, 24, 467-475.

Bumrungsri, S., Sripaoraya, E., Chongsiri, T., Sridith, K., \& Racey, P. A. (2009). The pollination ecology of durian (Durio zibethinus, Bombacaceae) in Southern Thailand. Journal of Tropical Ecology, 25, 85-92.

Bumrungsri, S., Lang, D., Harrower, C., Sripaoraya, E., Kitpipit, K., \& Racey, P. A. (2013). The dawn bat, Eonycteris spelaea Dobson (Chiroptera: Pteropodidae) feeds mainly on pollen of economically important food plants in Thailand. Acta Chiropterologica, 15(1), 95-104.

Borissenko, A. V., \& Kruskop, S. V. (2003). Bats of Vietnam and adjacent territories. An identification manual. Geos, Moscow, pp. 203.

Caio, S. G. C., Baker R. J., \& Volleth, M. (2017). Chromosomal evolution in Chiroptera. Genes, 8(10), 272. https://doi.org/10.3390/ genes 8100272 .

Castro-Luna, A. A., Sosa, V. J., \& CastilloCompos, G. (2007). Bat diversity and abundance associated with the degree of secondary succession in a tropical forest mosaic in south-eastern Mexico. Animal Conservation, 10(2), 219-228.

Christine, L. J., Fletcher, C., \& Abd Rahman, K. (2013). Spatial effects of Virgin Jungle Reserves (Vjr) on the community of insectivorous bats in Peninsular Malaysia. Journal of Tropical Forest Science, 25(1), 118-130.

Collins, J. (ed.) (2016). Bat surveys for professional ecologist: Good practice guidelines ( $3^{\text {rd }}$ ed.). London: The Bat Conservation Trust.

Digana, P. B., Yapa, W. B., Randeniya, P. V., \& Ratnasooriya, W. (2011). Roost selection of the short-nosed fruit bat, Cynopterus spp. in Sri Lanka. Journal of Science of the University of Kelaniya Sri Lanka, 1(0), 1521.

Edy Izzady Zulmahadi \& Abu Rahman Abu Talib. (2008). Kepelbagaian spesies kelawar di Ladang Hutan UPMKB. Unpublished Report, Universiti Putra Malaysia Bintulu Sarawak Campus.

Fagan, K. E., Willcox, E. V., Tran, L. T., Bernard, R. F., \& Stiver, W. H. (2018). Roost selection by bats in buildings, Great Smoky Mountains National Park. The Journal of Wildlife Management, 82(2), 424-434. Doi: 10.1002/jwmg.21372

Farah Awatif Khalid \& Nor Afiedatul Akmal. (2009). Kajian Kelawar Insektivora Hutan Ladang UPMKB. Unpublished Report, Universiti Putra Malaysia Bintulu Sarawak Campus.

Faridah-Hanum, I. (1999). Plant diversity and conservation value of Ayer Hitam Forest, Selangor, Peninsular Malaysia. Pertanika Journal Tropical Agricultural Science, 22(2), 73-83.

Francis, C., \& Hill, J. E. (1986). A review of the Bornean Pipistrellus (Mammalia: Chiroptera). Mammalia, 50, 43-56. http:// dx.doi.org/10.1515/mamm.1986.50.1.43

Francis, C. M. (2019). Field guide to the mammals of South-East Asia (2nd ed.). London: Bloomsbury Wildlife.

Francis, C. M. (1989). A comparison of mist nets and two types of harp traps for capturing bats. Journal of Mammalogy, 70, 865-870.

Gaisler, J., Zukal, J., Rehak, Z., \& Homolka, M. (1998). Habitat preference and flight activity of bats in a city. Journal of Zoology, 244, 439-455.

Haji Idris, H. N. (2012). Brunei today (A. M. Haji Mohammad, S. S. Haji Julaini, \& D. N. Pg. Haji Bakar, Eds.; 4th ed., Vol. 14). English News Division Information Department. http://www.information.gov. bn/Brunei\%20Today\%20PDF\%20Library/ Brunei\%20Today\%20sept2012.pdf

Happold, D. C. D., \& Happold, M. (1990). The domiciles, reproduction, social organization and sex ratios of The Banana Bat Pipistrellus 
nanus (Chiroptera, Vespertilionidae) in Malawi, Central Africa. Z. Säugetierkd, 55, 145-160.

Haziri, R., \& Aijam Myustaqeen, R. (2004). Kajian Awal Komposisi Spesies Kelawar Pemakan Buah Universiti Putra Malaysia Kampus Bintulu. Unpublished Report, Universiti Putra Malaysia Bintulu Sarawak Campus.

Ibrahim, A., Musa, N., Mohd. Top. M., \& Zakaria, M. (2013). Reproductive patterns of Cynopterus brachyotis (Dog-Faced Fruit Bat) in Bintulu, Sarawak. PERTANIKA Journal of Tropical Agricultural Science, $36,47-54$.

Ideris, A (2016, May 29). Membudayakan kelestarian kawasan hijau. Berita Harian, p.10.

IUCN (2020). The IUCN Red List of Threatened Species. Version 2020-2. https://www. iucnredlist.org. Accessed on 09 July 2020.

Jambari, A., Rajagopal, S., \& Azmi, Y. (1999). Short notes the vertebrates fauna of Ayer Hitam Forest Reserve, Puchong, Selangor. PERTANIKA Journal of Tropical Agricultural Science, 22(2), 179-184.

Jayaraj, V. K., Daud, S. H. M, Azhar, M. I., Sah, S. A. M., Mokhtar, S. I., \& Abdullah, M. T. (2013). Diversity and conservation status of Mammals in Wang Kelian State Park, Perlis. Malaysia Check List, 9(6), 14391448.

Jayaraj, V. K., Ketol, B., Anwarali, F. A. K., Hall, L. S., \& Abdullah, M. T. (2006). Bat survey of Mount Penrisen and notes on the Rare Kerivoula minuta, Kerivoula intermedia and Hipposideros coxi in Sarawak, Borneo. Journal of Biological Sciences, 6, 711-716.

Jayaraj V. K., Ketol, B., Marni, W., Sait, I., Mortada, M. J., Anwarali, F. A. A., Fong, P. H., Hall, L. S., \& Abdullah, M. T. (2011). Comparative distribution and diversity of bats from selected localities in Sarawak. Borneo Journal of Resource Science and Technology, 1, 1-13.

Jayaraj, V. K., Tahir, N. F., Udin, N. A., Baharin, N. F., Ismail, S. K., \& Zakaria, S. N. (2012). Species diversity of small mammals at
Gunung Stong State Park, Kelantan, Malaysia. J Threat Taxa, 4(6), 2617-2628.

Joann, C. L., Fletcher, C., \& Rahman, K. A. (2013). Spatial effects of virgin jungle reserves (VJR) on the community of insectivorous bats in Peninsular Malaysia. Journal of Tropical Forestry Science, 25(1), 118-130.

Jung, K., \& Kalko, E. K. V. (2011). Adaptability and vulnerability of high flying neotropical aerial insectivorous bats to urbanization. Diversity and Distribution, 17(2), 262-274.

Khan, F. A. A., Sazali, S. N., Jayaraj, V. K., Aban, M. S., Zaini, K., Ketol, B., \& Abdullah, M. T. (2007). Bats of Bako National Park, Sarawak, Malaysian Borneo. Sarawak Museum Journal, 63(84), 267.

Khan, F. A. A., Shazali, N., Latip, N., \& Azhar, I. (2019). Short communication: Into the heart of Borneo: Mammals of Upper Baleh, Sarawak. Journal of Sustainability Science and Management, 14(2), 173-182.

Khan, F. A. A., Swier, V., Solari, S., Larsen, P. A., Ketol, B., Marni, W., Ellaguipillay, S., Lakim, M., Abdullah, M. T., \& Baker, R. J. (2008). Using genetics and morphology to examine species diversity of Old World bats: Report of a recent collection from Malaysia. Occasional Papers of the Museum of Texas Tech University, 281, 1-28.

Kingston, T., Juliana, S., Nurul-Ain, E., Hashim, R., \& Zubaid, A. (2012). The Malaysian Bat Conservation Research Unit: From a National Model to an International Network. Malaysian Applied Biology, 41(2), 1-10.

Kingston, T., Lim, B. L., \& Zubaid, A. (2009). Bats of Krau Wildlife Reserve. Bangi: Penerbit Universiti Kebangsaan Malaysia. pp. 145.

Kitchener, D., \& Maharadatunkamsi. (1991). Description of a new species of Cynopterus (Chiroptera: Pteropodidae) from Nusa Tenggara, Indonesia. Record of Western Australia Museum, 15, 307-363.

Kofron, C. P. (1994). Bamboo-roosting of the Thick-thumbed Pipistrelle Bat (Glischropus tylopus) in Borneo. Mammalia, 58, 306309. 
Krutzsch, P. H. (2000). Anatomy, physiology and cyclicity of the male reproductive tract. In E. G. Crichton \& P. H. Krutzsch (Eds.), Reproductive biology of bats (pp. 91-155). https://doi.org/https://doi.org/10.1016/ B978-012195670-7/50005-9

Lesinski, G., Fuszara, E., \& Kolwaski, M. (2000). Foraging areas and relative density of bats (Chiroptera) in differently human transformed landscapes. Z Saugetierkd, 65, 129-137.

Lim, L. S., Csorba, G., Wong, C. M., Zubaid, A., Rahman, S. P. H., Jayaraj, V. K., Khan, F. A. A., Huang, J. C. C., Najimudin, N., \& Gorfol, T. (2016). The systematic position of Hypsugo macrotis (Chiroptera: Vespertilionidae) and a new record from Peninsular Malaysia. Zootaxa, 4170(1), 169-177. http://doi.org/10.11646/zootaxa. 4170.1.10.

Lim, L. S., Mohd-Adnan, A., Zubaid, A., Struebig, M. J., \& Rossiter, S. J. (2014). Diversity of Malaysian insectivorous bat assemblages revisited. Journal of Tropical Ecology, 30(02), 111-121.

Lim, L. S., Struebig, M. J., Nor Zalipah, M., Mohd-Adnan, A., Senawi, J., Zubaid, A., Mohd Sah, S. A., \& Rossiter, S. J. (2019). Bats from the understorey of lowland tropical rainforests across Peninsular. Malaysia Journal of Bat Research \& Conservation, 12(1), 68-82.

Lim, V. C., Ramli, R., Bhassu, S., \& Wilson, J. J., (2017). A checklist of the bats of Peninsular Malaysia and progress towards a DNA Barcode Reference Library. Plos One, 12(7). https://doi.org/10.1371/journal. pone. 0179555

Marina Mohd. Top@ Mohd. Tah, Noraini Che Ahmad Nordin \& John Keen Chubo. (2017). Understorey bats diversity in Compartment 15, Ayer Hitam Forest Reserve (AHFR), Puchong, Selangor, Malaysia. Proceeding of the 5th International Conference on Natural Resources in The Tropics (NRrop5).

Martínez-Ferreira, S. R., Alvarez-Añorve, M. Y., Bravo-Monzón, A. E., Montiel-González, C., Flores-Puerto, J. I., Morales-Díaz, S. P., Chiappa-Carrara, X., Oyama, K., \& Avila-
Cabadilla, L. D. (2020). Taxonomic and functional diversity and composition of bats in a Regenerating Neotropical Dry Forest. Diversity, 12, 0332.

Matthew, J. S., Birute, M. F. G., \& Suatma. (2006). Bat diversity in Oligotrophic Forest of Southern Borneo. Oryx, 40(4), 447-455. https://doi.org/10.1017/ s0030605306001190

Mazliawati, A., \& Mc. Eddy, J. (2006). Kajian Kepelbagaian Spesies Dan Status Pembiakan Kelawar Pemakan Buah dan Pemakan Serangga Di Universiti Putra Malaysia Kampus Bintulu. Unpublished Report, Universiti Putra Malaysia Bintulu Sarawak Campus.

Medway, L. (1969). The wild mammals of Malaya. London: Oxford University Press.

Medway, L. (1983). The wild mammals of Malaya and Singapore ( $2^{\text {nd }}$ ed.). Singapore: Oxford University Press.

Mikail, M., Putra, T. A. T. R., Suri, A. S., Hezmee, M. N. M., \& Marina, M. T. (2017). Preliminary study of Malaysian fruit bats species diversity in Lenggong Livestock Breeding Center, Perak: Potentialrisk of spill over infection, Veterinary World, 10(11), 1297-1300.

Mohamad Syafiq Che Shaffine \& Siti Sarah Ab. Rahim. (2010). Projek kepelbagaian dan kelimpahan spesies kelawar di UPMKB, Sarawak. Unpublished Report, Universiti Putra Malaysia Bintulu Sarawak Campus.

Mohd. Azlan, J., Sharma, R. S. K., \& Zakaria, M. (2000). Species diversity and relative abundance of understorey bats at Air Hitam Forest Reserve, Selangor, Malaysia. Malayan Nature Journal, 54(1), 49-55.

Mohd-Azlan, J., Kaicheen, S. S., Lok, L., \& Lawes, M. J. (2019). The role of forest fragments in small mammal conservation in an oil palm plantation in Northern Sarawak, Borneo. Journal of Oil Palm Research, 31(3), 422-436.

Mohd Firdaus Khairuddin \& Mohd Farhan Che Hasim. (2008). Kajian Kepelbagaian Spesies dan Status Pembiakan Kelawar Pemakan Buah Di UPMKB. Unpublished 
Report, Universiti Putra Malaysia Bintulu Sarawak Campus.

Mohd. Hafis Ngadimin \& Norasilah Latiff. (2009). Kepelbagaian Spesies Kelawar Pemakan Buah di Hutan Nirwana UPMKB. Unpublished Report, Universiti Putra Malaysia Bintulu Sarawak Campus.

Mohd-Hanif, R. M. D., Nur-Aida, M. T., Zahirunisa, A. R., Mohd-Ridwan, A. R., \& Abdullah, M. T. (2015). Contribution of regenerated forest in conservation of bats in Peninsular Malaysia. Journal of Tropical Forest Science, 27(4), 506-516.

Mohd Hazlan, A. A., \& Nurul Aidah, B. (2008). Kepelbagaian Spesies Kelawar Pemakan Serangga di Ladang Hutan, Universiti Putra Malaysia Kampus Bintulu. Unpublished Report, Universiti Putra Malaysia Bintulu Sarawak Campus.

Mohd-Ridwan, A. R., Nurul Farah Diyana, A. T., Mohamad Haikal, E., Görföl, G. T., Khan, F. A. A., \& Mohd-Azlan, J. (2018). Bats assemblage and lunar phase effect on bat activity at Mixed Dipterocarp Forest, Gunung Gading National Park, Sarawak, Borneo. Sains Malaysiana, 47(7), 13491357.

Mohd Zabidi, H., \& Siti Hawa, M. (2007). Kepelbagaian Spesies Kelawar di Ladang Hutan, Universiti Putra Malaysia Kampus Bintulu. Unpublished Report, Universiti Putra Malaysia Bintulu Sarawak Campus.

Moseley, M., Lim, T. W., \& Lim, T. T. (2012). Fauna reported from Batu Caves, Selangor, Malaysia: Annotated checklist and bibliography. Cave and Karst Science, 39(2), 77-92.

Muhammad Hafizuddin Hashim \& Sonetha Sining. (2009). Projek Kajian Kepelbagaian Spesies Kelawar Pemakan Buah di Hutan Ladang UPM Kampus Bintulu, Sarawak. Unpublished Report, Universiti Putra Malaysia Binulu Sarawak Campus.

Murni Samsuddin \& Juliana Nordin. (2009). Kepelbagaian dan Kekayaan Spesies Kelawar Pemakan Serangga di Hutan Nirwana UPMKB. Unpublished Report, Universiti Putra Malaysia Bintulu Sarawak Campus.
Norfahiah, M., Azema, I., Marina, M. T., \& Zakaria, M. (2012). Status and distribution of non-volant small mammals in Universiti Putra Malaysia Bintulu Sarawak Campus (UPMKB). PERTANIKA Journal of Tropical Agricultural Science (JTAS), 35, 363-369.

Norisah, J., \& Hafizzuddin, H. (2008). Kepelbagaian Spesies Kelawar di Hutan Nirwana, Universiti Putra Malaysia Kampus Bintulu. Unpublished Report, Universiti Putra Malaysia Bintulu Sarawak Campus.

Norsham, Y., Shariff, F., Norhayati, A., Nordin, M., \& Lim, B.L. (1999). Pre-logging survey of mammal fauna at Sungai Weng sub-catchment, Ulu Muda Forest Reserve Forest Reserve, Kedah. Journal of Wildlife and Parks, 17, 28-43.

Nuratiqah, A. R., Azhar, B., Salmah, Y., Ng, Y. F., Ting, J. S., \& Zubaid, A. (2017). Man-made maternity roost selection by Scotophilus kuhlii (Lesser Asiatic Yellow Bat) in two anthropogenically altered habitats. Malayan Nature Journal, 69(1), 31-39.

Ong, K. H., John Keen, C., Roland Kueh, J. H., \& Marina, M. T. (2008). Protecting of the last frontier: The role of Universiti Putra Malaysia Bintulu Campus in Biodiversity Conservation. Proceedings of the 10th MSAB Symposium, Kuching.

Paiman, B., \& Amat, R. Y. (2007). Ayer Hitam Forest Reserve: Multimedia Super Corridor Community Heritage. Serdang: Faculty of Forestry UPM.

Payne, J., \& Francis, C. M. (1985). A field guide to the mammals of Borneo. Kota Kinabalu: The Sabah Society and World Wildlife Fund Malaysia, pp. 332.

Payne, J., \& Francis, C. M. (2007). A field guide to the mammals of Borneo. Kota Kinabalu: The Sabah Society and WWF Malaysia. $332 \mathrm{pp}$.

PERHILITAN. (2017), Red list of Mammals for Peninsular Malaysia Version 2.0. Kuala Lumpur: Department of Wildlife and National Parks Peninsular Malaysia. 150p. 
Phillipps, Q., \& Phillipps, K. (2018). Phillipps' field guide to the mammals of Borneo and their ecology: Sabah, Sarawak, Brunei, and Kalimantan ( $2^{\text {nd }}$ ed.). UK: John Beaufoy Publishing Ltd.

Ratnam, L., Lim, B. L., \& Hussein, N. A. (1995). Mammals of the Sungai Singgor area in Temengor Forest Reserve, Hulu Perak, Malaysia. Malayan Nature Journal, 48, 409-423.

Ritauddin Abd Razak \& Aminah Alias. (2008). Kajian Kepelbagaian Spesies dan Status Pembiakan Kelawar Pemakan Serangga di Sekitar Kampus Universiti Putra Malaysia Kampus Bintulu. Unpublished Report, Universiti Putra Malaysia Bintulu Sarawak Campus.

Russo, D. G., Billington, F. Bontadina, J., Dekker, M., Dietz, S., Gazaryan, G., Jones, A., Meschede, H., Rebelo, G. R., \& Twisk, P. (2016). Identifying key research objectives to make European forests greener for bats. Frontiers in Ecology and Evolution, 4(87).

Sasidhran A/L Selvadurai \& Siti Nurfatin Sahidan. (2010). Kajian Kepelbagaian Kelimpahan Kelawar Pemakan Serangga Sekitar Hutan Nirwana dan Hutan Ladang $U P M K B$. Unpublished Report, Universiti Putra Malaysia Bintulu Sarawak Campus.

Scully, W. M. R., Fenton, M. B., \& Saleuddin, A. S. M. (2000). A histological examination of the holding sacs and glandular scent organs of some bat species (Emballonuridae, Hipposideridae, Phyllostomidae, Vespertilionidae, and Molossidae). Canadian Journal of Zoology, 78(4), 613-623.

Senawi, J. \& Norhayati, A. (2021). Bats of Malaysia. Putrajaya: Kementerian Tenaga dan Sumber Asli.

Senawi, J., Mahyudin, A., Daud, U. S., Amat. A., Lagundi, S., Gondilang, E., Sutail, E. Narimin, S., \& Azhar, I. (2020). Bat diversity in Imbak Canyon Conservation Area: Note on their Echolocation Calls and Ectoparasites. Journal of Tropical Biology and Conservation, 17, 217-232.

Shazali, N., Rahman, S. P. H., Tahir, N. F. D. A., Murni, R., Latip, N. A., Naharuddin, N. M., Azhar, I., McArthur, E., Khalik, M. Z.,
Rahman, M. R. A., \& Khan, F. A. A. (2016). Small mammals from Miri, north-eastern region of Sarawak, Malaysian Borneo: Note on new locality records. Check List, 12(2), 1863.

Shirley, A. P., David, J. W. L., Kingston, T., \& Benjamin, P. Y. H. (2005). The Microchiropteran bat fauna of Singapore. Acta Chiropterologica, 7(2), 237-247.

Simmons, N. B. \& Cirranello, A. L. (2020). Bat Species of the World: A taxonomic and geographic database. Accessed on 10/11/2021.

Sing, K. W., Khairunnisa, S., \& Wilson, J. J. (2013). Changing perspectives on the diversity of bats (Mammalia: Chiroptera) at Ulu Gombak since the establishment of the field study centre in 1965. The Raffles Bulletin of Zoology, 29, 211-217.

Springer, M. S. (2013). Phylogenetics: Bats united, microbats divided. Current Biology, 23(22), 999-1001.

Struebig, M. J., Bozek, M., Hildebrand, J., Rossiter, S. J., \& Lane, D. J. W. (2012). Bat diversity in the lowland forests of the Heart of Borneo. Biodiversity and Conservation, 21(14), 3711-3727.

Syed Ahmad Hazman, S. H., \& Fatin Nazwa, A. (2008). Kepelbagaian Spesies dan Status Pembiakan Kelawar Pemakan Serangga di Hutan Nirwana, Universiti Putra Malaysia Kampus Bintulu. Unpublished Report, Universiti Putra Malaysia Bintulu Sarawak Campus.

Tan, K. H., Zubaid A., \& Kunz, T. H. (1998). Roost selection and social organisation in Cynopterus horsfieldii (Chiroptera: Pteropodidae). Malayan Nature Journal, 53(4), 295-298.

Tingga, R. C. T., Anwarali, F. A., Rahman, M. R. A., Senawi, J., \& Abdullah, M. T. (2012). Small mammals from Kuala Atok, Taman Negara Pahang, Malaysia. Sains Malaysiana, 41(6), 659-669.

Tingga, R. C. T., Mohd.-Ridwan, A. R., \& Fatin, N. R. (2020). Preliminary investigation on taxonomic status of sympatric Tylonycteris species in Malaysia. Malayan Nature Journal, 72(2), 143-146. 
van der Ree, R., \& McCarthy, M. A. (2005). Inferring persistence of indigenous mammals in response to urbanisation. Animal Conservation, 8(3), 309-319.

Widad, F., \& Wong, C. H. (2013). Bats diversity in Kolej Universiti Sains dan Teknologi Malaysia (KUSTEM). International Journal for Innovation Education and Research, 1-03.

Wildlife Conservation Act. 2010. Laws of Malaysia. Act 716, Wildlife Conservation Act 2010. Available from: http:// www. wildlife.gov.my/images/stories/akta/ Wildlife $\%$ 20Conservation $\% 20$ Act $\% 20$ 2010\%20Act716.pdf

William-Dee, J., Khan, F. A. A., Rosli, Q., Morni, M. A., Azhar, I., Lim, L. S., Tingga, R. C. T., \& Abdul Rahman, M. R. (2019). Comparative distribution of small mammals diversity in protected and non-protected area of Peninsular Malaysia. Tropical Life Sciences Research, 30(2), 131-147.

Yoh, N., Azhar, I., Fitzgerald, K. V., Yu, R., Smith-Butler, T., Mahyudin, A., \& Kingston, T. (2020). Bat ensembles differ in response to use zones in a Tropical Biosphere Reserve. Diversity, 12(2), 60.

Zachos, F. E. (2020). D. E. Wilson and R. A. Mittermeier (chief editors): Handbook of the Mammals of the World. Vol. 9. Bats. [Review of the book Handbook of the Mammals of the World. Vol. 9. Bats by D. E. Wilson and R. A. Mittermeier]. Mammalian Biology, 100, 335.

Zubaid, A. (1993). A comparison of the bat fauna between a primary and fragmented secondary forest in Peninsular Malaysia. Mammalia, 57(2), 201-206. 